\title{
View on the Development Choice of the Contemporary Chinese Culture from the Prevalence of the Utilitarian Culture
}

\author{
Chunfang Wang \\ School of Humanities, Jilin Agricultural University, Changchun, 130118, China \\ wangchunfang1975@tom.com
}

Keywords: utilitarianism; cultural value; cultural development.

\begin{abstract}
Utilitarianism pursues pleasure and happiness; realizes the maximization of the individual interests, which has wide impact on western and Chinese society. Under the guidance of construction target of socialist cultural power, we must view utilitarianism correctly, affirm its rationality at the same time, and look for the reasonable path of the Chinese culture development from our own social system changes, the comprehensive understanding of western culture and the rational criticism inherit of the traditional culture.
\end{abstract}

\section{Introduction}

Over 30 years reform and opening up, along with the rapid development of the economy, "China's rise" has become the world-recognized undisputed fact. In the change and transformation process of economic and social development, the developments of Chinese culture also are confronted with the challenge of innovation and rise. Report on the Eighteenth National Congress of the Communist Party of China point out, the construction of socialist cultural power must take socialist cultural development road with Chinese characteristics, rich people's spiritual and cultural life, strengthen the system construction of the socialist core value, enhance cultural overall strength and competitiveness, and thus improve citizens' moral quality comprehensively, this is the main task of our cultural construction. However, with the change of social system, especially the transformations of economic system, utilitarian culture that seek maximization of the interests become popular, influence the social economic, political life and the people' lives. Utilitarian culture as foundation for the western ethics, advocating the pursuit of happiness is everyone's equal right, Chinese people never consider individuals, did not mention individual interests in the past, this value proposition are overthrown, but the pursuit of happiness is not completely unrestrained self-indulgence, it still cannot be divided with the human morality, law and tradition.

\section{The Prevalence of Utilitarian Culture in Social System Change}

Utilitarian culture is mainly manifested in two aspects: "one is that the utility is regarded as main purpose of social behavior; the second is that the utility as value tendency of cultural behavior" [1]. The most direct embodiment of the socialist economic system reform is transformation from "planned economy" to "market economy", and the core requirement of the market economy is maximization of the interests, carry out the principle of efficiency first. The consequence that pursues maximum market benefits in economic production field makes people from the past equalitarianism, egalitarianism to the reasonable demands profit and money. Utilitarian theory thinks that "seek advantages and avoid disadvantages" is human nature, the pursuit of interests is the behavior objective of people, all actions that are in order to realize the purpose of the maximum joy and happiness are good and right, and vice is evil and unjustified. China in the tide of market economy, from the past impoverished life situation into the pursuit of earning money through various means, and this pursuit is not opposed by society, it become a kind of socially accepted orientation in line with the market economy value, and this idea rapidly popularizes and occupy a place of social culture. 
We must admit that the utilitarian cultural values liberate the people's thought to a some extent, the pursuit of happiness life is goal to be advocated by human, the pursuit of interests has its rationality, but this requirement does not mean that our cultural value is taken gainfulness and money first for granted, or the utilitarianism is narrowly understood " egoism", itself is a mistake. The narrow utilitarianism cause a direct result in China, which is money worship, indulges self, endless greed. This value in the daily social life, make a lot of people in a state of anomie, lack of due behavior rules, lost goal in the life value, moral decline, corruption, interpersonal alienation and indifference, make people lost life direction, resulting in the chaos of the social life.

\section{Rethink Prevalence of Utilitarian Culture from the Collision between Chinese and Western Culture}

The Westernization Movement, the 1911 Revolution and the May 4th Movement three major social changes have endured in China's modern history, respectively, it is also the "from the implement level to system level, from the institution level to cultural concept level' development logic summarized by many scholars later". China's social development seems to start this development logic over again for more than 30 years reform and opening-up, start from the "four modernizations" implement level to the institution reform, the resistance and discomfort are encountered in the process of institution reform, cause people to find the root of solving social problems from the cultural concept naturally, it is the time background that cause collision between Chinese and western culture. "standard of truth" big discussion is an important clean to imprison the people' rigid ideology for many years, in the process of cleaning, people start to change the basic attitude for western culture, from the past fear, alert and rejection to acceptance, approval and follow.

Along with the arrival of the global society, western culture as the cradle of global civilization, which begin to spread around the world. It should be said that before the reform and opening up, the development of Chinese society is divorced from the mainstream culture of modern world. After adopting opening-up policy, we are not only confronted with the challenges of science and technology, the challenges of economic development, but also face new cultural challenge. To meet this challenge is our necessary choice into the mainstream culture of modern world.

When we are faced with prevalence of utilitarian culture and frequent appearance of many social anomie problems, many people think that it is dual effect that the reform and openness bring, namely the more economic development causes people' utilitarian tendency to be more serious, thus make social moral system face major crisis. In fact, globalism represented by western culture, which emphasizes the " mankind has entered into the era of globalization, convergence in information, economy and lifestyle, culture are also gradually convergent, the human basically recognized universal culture principles are formed" [2], that is, cultural transmission as the globalism, which is social existent reality that is not transferred by the people' will, we can't refuse and don't escape.

The "individualism", "egoism" are derived from western utilitarianism, which has brought China's current prevailing utilitarian culture not so much, than China itself has been a huge success in "implements level" change, but the change of institution level seriously lag, which cause the numerous difficulties that the cultural construction in our country faces currently. Max weber also pointed out: "desire of profit, the pursuit of profit and money (and it is the largest possible amount of money), it is not coherent with the capitalism. Such desire exists and exists in all the people all the time" [3].

China's reform and openness arouse people's material desires, and the institutions are not able to create a condition, make these desires build culture goal for social acceptance, and provide the necessary conditions for achieving this goal. Materialism at that time, people' value orientation deviation--the infinite pursuit of utility, it has become a necessity. Therefore, the prevalence of utilitarianism is completely ascribed to the influence of western culture, and that is the perversion of western culture, but also is a self-deception that shirks ego responsibility. 


\section{Criticism of the Utilitarian Culture in the Integration of Tradition and Modern}

At present, our country is still in the transition period from tradition to modern, traditional and modern culture mingle, conflict, but due to the rapid penetration of western culture, the characteristics of diversified culture are shown. For the criticism of traditional culture, the May 4th Movement and the Great Cultural Revolution are the most typical, because of total westernization or revolution in the end, two cultural criticism did not establish new culture in accordance with law of social development, and ended in failure. Therefore, Reviewing the Chinese civilization thousands of years, people start rationally to criticize and inherit the traditional culture.

Chinese traditional culture with its ultimate perfect "ethical culture", "moral culture", which make people very difficult to realize their value pursuits in real life. With invasion of utilitarian culture, the China traditional "the gentleman does not say profit" ascetic values has been weakened, people more and more pay attention to their personal interests. But "from the ultimate purpose of human existence and development, interests, utility and morality all have value for people", [4] because material benefits meet people's material needs, while morality is people' the spiritual needs with highest level. Thus, as Kant advocated that the world most formidable should be "inner moral law," justice, fairness these value targets are still sacred value pursuit of human beings.

We can't fade "debate over justice and benefit" in traditional culture; justice and morality are the basic content of traditional morality in the Chinese nation. "Debate over justice and benefit" just make people rethink the relationship problems between the morality and material interests. Confucian ethics also discuss benefits, but against the pursuit of personal benefit by hook or by crook, oppose behavior that meet personal desires and benefit oneself at other people's cost, injure the public interest to benefit one's private interest, trample moral and law line. If the people dare not publicly propose their legitimate interests in front of "justice outweigh benefit" moral law in the past, then through the reference and criticism of utilitarianism, we think that the "take justice instead of the profit", " think of justice when seeing the benefit " these traditional ideology and culture still should be inherited," "unify justice and benefit" should be as the basic content of socialist culture, which are emphasis and advocacy on economic ethics.

\section{College Education Guided by Ecological Utilitarian Value}

Besides moral wisdom with "pursue interests and avoid risks", "pursuit of interest" content, utilitarianism also has a very profound influence on education. The explanation of utilitarianism on education is "beneficial to useful learning ", young people accept education, which is for stable income and social acceptance. Utilitarianism change education goal into personal things, thus it is severely underestimated. Tension between university idealism and utilitarianism are grasped under the socialist culture, which are important content of ecological utilitarian value, it has important practical significance to reverse China contemporary higher education "academic crisis" and "cultural crisis", for the balanced sustained development of social economy, politics, culture.

In view of science, utilitarian view of science think that science must be rooted in the society, served the society, driven by society, and the echoed university education make their scientific research and social need, especially closely associated with the production. The author thought that any single view of science cannot promote the progress and innovation of higher education for long, colleges and universities should grasp the tension between idealism and utilitarianism, especially our country is in the high-speed economic development, implement the strategy of rejuvenating China through science and technology today, more make university education target the society and future, follow the law of scientific development, cultivate the throngs of talents concentrated on study of natural science at the same time, pay close attention to university education and the social value of college students, under the guidance of ecological utilitarian value, form the benign interaction, promote the construction of socialist modernization.

On the education purpose and teaching content, utilitarianism take service of the society as the fundamental goal, university education make scientific system that connect with each other separate 
broken and scattered knowledge areas, make the instrumental rationality of education beyond its value rationality, the university as vocational training place, which conveys special talents for the society. In essence, higher education should be the intermediary of social life and college life, start from social need and students' personal ideal need, need carry on the design, control and operation. Colleges and universities are specially provided the necessary humanistic quality, knowledge and intellectual skills for youth, and they can make a choice in various possible social environment and way of life. So on balance of idealism and utilitarianism, vocational education should have a place in the quality education, but they must be arranged under a broader and more comprehensive, more education of subjectivity, and must be students' independent choice with the ability to choose, rather than replace general education or part of the compulsory courses. This requires specialization and meets education of social labor division, must after college students are given adequate opportunity to find interest, when they are willing to choose the professional education in choice range permitted by natural talent, and that is reasonable.

\section{Conclusion}

The prevalence of utilitarian culture has a huge impact on Chinese society, people's self-seeking maximization in economy field lead to environmental destruction, resource exhaustion, the sustainable developments are threatened; government achievements are utilitarian in politic filed, the concept that economic benefit is supreme lead to intense relationship between the government and the people; the utilitarianism in the cultural field make people' value orientation into nothingness, people are confused about what to do. Therefore, the change of institution and system are promoted, the contradictions of "fairness" and "efficiency" are handled well, the traditional and western culture are integrated again, the utilitarian culture are reasonably integrated into our new culture construction, make our traditional idealism and pragmatism combined effectively, so as to promote the innovation and improvement of Chinese cultural construction .

\section{References}

[1] Bing Zheng: Transition of the Contemporary Cultural Contradictions and Philosophical Discourse System, Social Sciences in China, 2011, No.2, p.14, p.16.

[2] Max Weber, The Protestant Ethic and Capitalist Spirit, Yu Xiao, Chen Weigang translate, Beijing: SDX Joint Publishing Company, 1987, p.7.

[3] Liang Limin. The Limitation of Utilitarian Economic Ethics Thought ", Economic Research Guide, 2011, No.17, p.10. 